\title{
THE ANTISTREPTOLYSIN TITER IN RHEUMATIC FEVER, ARTHRITIS AND OTHER DISEASES
}

\author{
By JOSEPH J. BUNIM AND CURRIER McEWEN \\ (From the Third (New York University) Medical Division and the Laboratories of Pathology, \\ Bellevue Hospital, and the Department of Medicine, New York \\ University College of Medicine)
}

(Received for publication August 18, 1939)

Since 1933 a number of serologic tests have been made in the study of patients with rheumatic fever, arthritis, and several other diseases, who have come under the authors' care. These tests include gonococcus complement fixation, hemolytic streptococcus agglutinin and precipitin tests, and antifibrinolysin and antistreptolysin titrations. A preliminary report of the results of these was made in 1936 (1). The purpose of the present report is to give a more detailed analysis of the results of antistreptolysin determinations performed from 1933 to the end of 1938.

We have determined the titer of the serum of normal subjects and patients with the following diseases:

1. Scarlet fever

2. Rheumatic fever and chorea

3. Rheumatoid and other types of arthritis

4. A few cases of such miscellaneous conditions as erythema nodosum, pericarditis, lupus erythematosus disseminatus, and periarteritis nodosa.

The cases studied were from the Third (New York University) Medical Division of Bellevue Hospital and from the Arthritis Clinics of New York University College of Medicine. The sera were analyzed without knowledge of the clinical diagnoses. The serological determinations were done according to the method of Hodge and Swift (2). Because of the time required for antibody formation to take place, no patient with antistreptolysin titer within the normal range was included in our analysis unless serial determinations were made over a period of at least 4 weeks. ${ }^{1}$ In all, 1,539 determinations have been made on the sera of 817 patients with the diseases listed above. We have also collected and rearranged results

1 Except in the scarlet fever patients, some of whom were followed only 3 weeks. obtained by others for the purpose of convenient reference.

\section{ANTISTREPTOLYSIN TITER IN NORMAL SUBJECTS}

An analysis was made of the sera of 39 normal persons consisting of medical students and physicians. These subjects were free from any upper respiratory infection or other illness for a minimum of 4 weeks prior to examination. The titer was 25 units or less in 21,50 units in 12 , 100 units in 5 , and 150 units in 1 person.

Table I summarizes these results and those of other investigators. The median titer reported by most workers is 100 units or less. Myers and Keefer found the average (not median) titer to be 213 units. They used sheep erythrocytes instead of the customary rabbit cells, however, and von Hellens (3) had observed that sheep cells were more resistant to hemolysis by streptolysin than rabbit erythrocytes.

In view of our results we have considered 100 units per cc. of serum as the upper limit of normal. However, a rise in titer in serial tests, even though not exceeding 100 units, suggests hemolytic streptococcus infection, as is shown below in tests performed on patients with scarlet fever.

\section{ANTISTREPTOLYSIN TITER IN SCARLET FEVER}

In 1934 we studied 21 cases of scarlet fever admitted to Willard Parker Hospital during the months of January and February of that year. Blood was collected from each patient on the day of admission and again upon discharge. ${ }^{2}$ As will be seen from Table II, all patients except 1 had a normal antistreptolysin titer on admission. All but 4 showed an elevation of antistreptolysin titer during the course of the disease, although only 10

2 The authors are indebted to Dr. Jesse M. Bullowa and Dr. I. H. Scheffer for permission to obtain these sera. 
TABLE I

Normal antistreptolysin titer (units per cc.) obtained by various observers

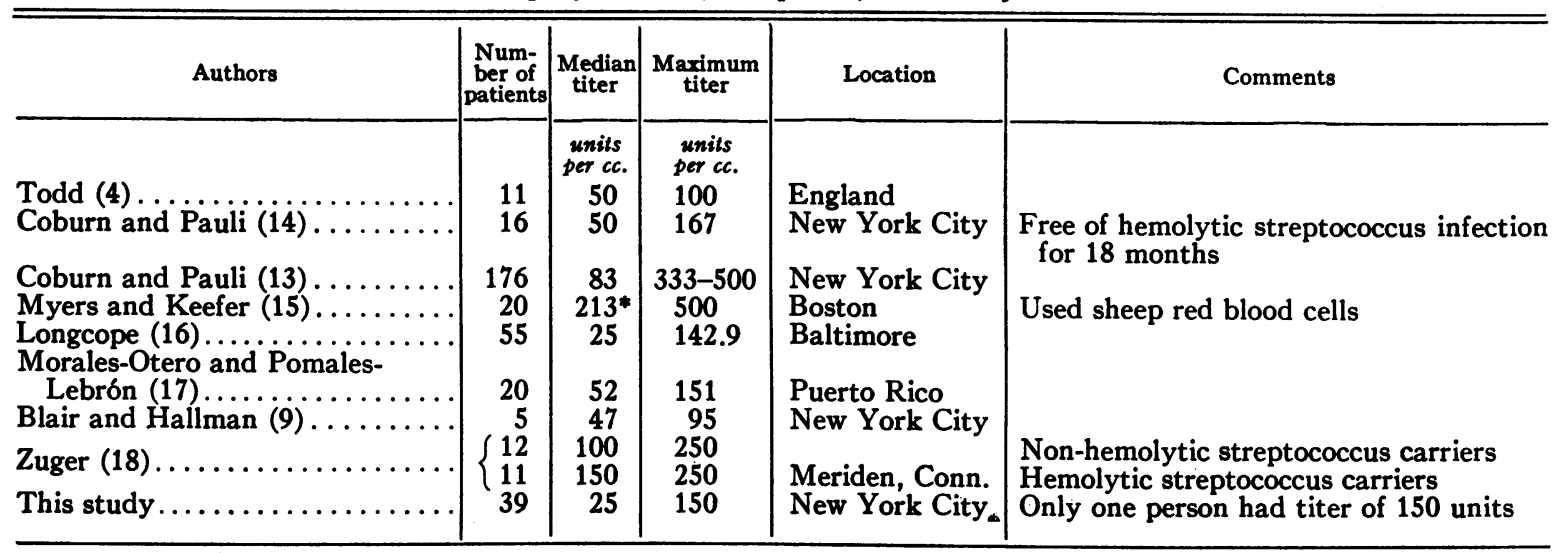

* Average-not median.

TABLE II

Antistreptolysin determinations in 21 patients with scarlet fever

\begin{tabular}{|c|c|c|c|}
\hline Patient & $\begin{array}{l}\text { Days between } \\
\text { onset and } \\
\text { admission }\end{array}$ & $\begin{array}{l}\text { Antistreptolysin } \\
\text { titer on } \\
\text { admission }\end{array}$ & $\begin{array}{l}\text { Antistreptolysin } \\
\text { titer } 3 \text { to } 4 \\
\text { weeks later }\end{array}$ \\
\hline 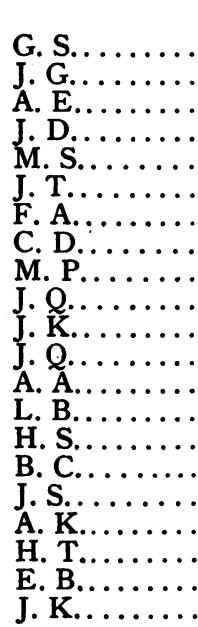 & $\begin{array}{l}3 \\
2 \\
6 \\
6 \\
6 \\
4 \\
4 \\
1 \\
4 \\
2 \\
8 \\
1 \\
4 \\
8 \\
2 \\
6 \\
5 \\
4 \\
4 \\
1 \\
2\end{array}$ & $\begin{array}{c}\text { urits per cc. } \\
\text { Less than } 25 \\
25 \\
25 \\
25 \\
50 \\
50 \\
50 \\
50 \\
25 \\
50 \\
100 \\
100 \\
25 \\
50 \\
\text { Less than } 25 \\
100 \\
25 \\
25 \\
\text { Less than } 25 \\
200 \\
50\end{array}$ & $\begin{array}{c}\text { urits per cc. } \\
25 \\
25 \\
50 \\
50 \\
50 \\
100 \\
100 \\
100 \\
100 \\
100 \\
100 \\
150 \\
150 \\
150 \\
200 \\
200 \\
400 \\
400 \\
400 \\
500 \\
700\end{array}$ \\
\hline
\end{tabular}

reached an abnormal level during the period of observation. None of the patients stayed in the hospital for longer than 4 weeks, and it may be that more would have shown an abnormal titer if they had been followed over a longer period. Table III.summarizes results of others.

\section{ANTISTREPTOLYSIN TITER IN RHEUMATIC FEVER}

\section{A. Carditis, polyarthritis and inactive rheumatic} heart disease

In 1932 Todd (4) and Coburn and Pauli (5) reported the antistreptolysin titer of patients with
TABLE III

Scarlet fever: collected results*

\begin{tabular}{|c|c|c|c|c|c|c|}
\hline Authors & $\begin{array}{l}\text { Num- } \\
\text { ber of } \\
\text { pa- } \\
\text { tients }\end{array}$ & $\begin{array}{l}\text { Number } \\
\text { of deter- } \\
\text { minations }\end{array}$ & $\begin{array}{c}\text { Authors' } \\
\text { maximum } \\
\text { normal }\end{array}$ & $\begin{array}{c}\text { Num- } \\
\text { ber of } \\
\text { patients } \\
\text { above } \\
\text { normal }\end{array}$ & $\begin{array}{c}\text { Per } \\
\text { cent of } \\
\text { patients } \\
\text { above } \\
\text { normal }\end{array}$ & $\begin{array}{c}\text { Period of } \\
\text { obeervation }\end{array}$ \\
\hline Todd (4)........ & 8 & Not given & $\begin{array}{c}\text { units } \\
\text { per ce. } \\
100\end{array}$ & 8 & 100 & $\begin{array}{c}\text { During con- } \\
\text { valescence }\end{array}$ \\
\hline $\begin{array}{l}\text { Myers and } \\
\text { Keefer (15) ... }\end{array}$ & 71 & 71 & 200 & 63 & 89 & $\begin{array}{l}\text { During con- } \\
\text { valescence }\end{array}$ \\
\hline $\begin{array}{l}\text { Coburn and } \\
\text { Pauli (13).... } \\
\text { Longcope (8).... } \\
\text { Zuger (18) } \ldots \ldots\end{array}$ & $\begin{array}{l}10 \\
18 \\
12\end{array}$ & $\begin{array}{l}10 \\
35 \\
68\end{array}$ & $\begin{array}{l}100 \\
100 \\
150\end{array}$ & $\begin{array}{l}9 \\
8 \\
6\end{array}$ & $\begin{array}{l}90 \\
44 \\
50\end{array}$ & $\begin{array}{l}\text { Four weeks } \\
6 \text { to } 30 \text { weeks }\end{array}$ \\
\hline This study...... & 21 & 42 & 100 & 10 & 48 & 3 to 4 weeks \\
\hline Total.. & 140 & & & 104 & 74 & \\
\hline
\end{tabular}

* Where several determinations were recorded for a single patient, only the maximum titer was considered.

active rheumatic fever to be distinctly elevated and accepted this as immunological evidence that rheumatic fever is preceded by hemolytic streptococcus infection. Coburn and Pauli (5) found that this antibody was present in abnormal quantities in patients with active rheumatic fever even when they gave no history of a preceding upper respiratory infection or even when the throat culture was free of hemolytic streptococci.

Wilson, Wheeler and Leask (6), working in the same city, came to different conclusions from a study of 80 rheumatic children. Two-thirds of their patients experiencing rheumatic activity unassociated with respiratory infection did not exhibit a rise in titer. ${ }^{8}$

8 By a "rise" these authors do not refer to a rise above the normal level but above the basal level for rheumatic 
Todd (4), Griffiths (7), Longcope (8) and Blair and Hallman (9) report an elevated titer in 85 per cent to 100 per cent of patients with active rheumatic fever. In most of these reports no mention is made of the presence or absence of preceding respiratory infections or the results of throat cultures.

We have studied 171 adults with active rheumatic fever and 139 with inactive rheumatic heart disease. The patients were under observation on the wards and in the clinics for a period ranging from 4 weeks to several years. The criteria for activity were: (1) history of palpitation, precordial pain, fever, joint pains, or undue weight loss; (2) fever, tachycardia, gallop, changing murmurs or rhythm, pericardial friction rub, rheumatic skin manifestations, or subcutaneous nodules; (3) significant electrocardiographic changes; (4) elevated erythrocyte sedimentation rate or leukocytosis.

In Table IV we have divided the cases into an active and inactive group and have subdivided each group according to the presence or absence of an upper respiratory infection (" cold," sore throat, pharyngitis, tonsillitis, or bronchitis) within 4 weeks of serological studies. The patients having active disease have been further classified in relation to the presence of polyarthritis, carditis, or both. It is clear from this study that the median antistreptolysin titer of the patients with active rheumatic fever was above normal, while subjects observed for several months during comparatively good health. this was not true of the patients with inactive rheumatic heart disease. In the patients with manifestations of active rheumatic fever, the antistreptolysin titers were above 100 units in 76 per cent to 83 per cent of those who gave a history of preceding upper respiratory infection as compared with 54 per cent to 68 per cent of those without such a history (Figure 1). There was no significant difference between the patients who had rheumatic polyarthritis without carditis or

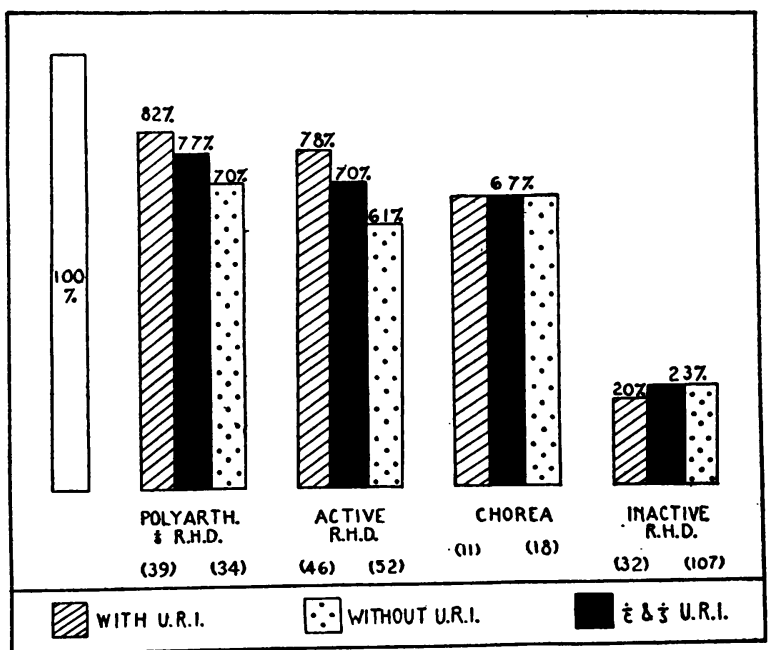

Fig. 1. Elevated Antistreptolysin Titer In 339 Rheumatic Subjects in Relation to UpPer RespiraTORY INFECTION

U. R. I. = upper respiratory infection $\dot{\overline{\mathrm{c}}} \& \dot{\mathrm{B}}=$ with and without

Polyarth. = polyarthritis

R. H. D. = rheumatic heart disease.

TABLE IV

Maximum antistreptolysin titer (units per cc.) in adult rheumatic subjects

\begin{tabular}{|c|c|c|c|c|c|c|c|c|}
\hline & \multicolumn{6}{|c|}{ Active rheumatic fever } & \multirow{2}{*}{\multicolumn{2}{|c|}{$\begin{array}{c}\text { Inactive rheumatic } \\
\text { heart disease }\end{array}$}} \\
\hline & \multicolumn{2}{|c|}{$\begin{array}{l}\text { Polyarthritis without } \\
\text { obvious carditis }\end{array}$} & \multicolumn{2}{|c|}{$\begin{array}{l}\text { Active carditis } \\
\text { with polyarthritis }\end{array}$} & \multicolumn{2}{|c|}{$\begin{array}{l}\text { Active carditis } \\
\text { without polyarthritis }\end{array}$} & & \\
\hline & $\begin{array}{l}\text { With upper } \\
\text { respiratory } \\
\text { infection }\end{array}$ & $\begin{array}{l}\text { Without } \\
\text { upper } \\
\text { respiratory } \\
\text { infection }\end{array}$ & $\begin{array}{l}\text { With upper } \\
\text { respiratory } \\
\text { infection }\end{array}$ & $\begin{array}{l}\text { Without } \\
\text { upper } \\
\text { respiratory } \\
\text { infection }\end{array}$ & $\begin{array}{l}\text { With upper } \\
\text { respiratory } \\
\text { infection }\end{array}$ & $\begin{array}{l}\text { Without } \\
\text { upper } \\
\text { respiratory } \\
\text { infection }\end{array}$ & $\begin{array}{l}\text { With upper } \\
\text { respiratory } \\
\text { infection }\end{array}$ & $\begin{array}{l}\text { Without } \\
\text { upper } \\
\text { respiratory } \\
\text { infection }\end{array}$ \\
\hline $\begin{array}{l}\text { Number of patients. } \ldots \\
\text { Average number of } \\
\text { bleedings............. } \\
\text { Median titers. . . . } \\
\text { Per cent of patients } \\
\text { above } 100 \text { units...... } \\
\text { Number of patients } \\
\text { above } 100 \text { units...... }\end{array}$ & $\begin{array}{c}39 \\
1.9 \\
250 \\
82 \\
32\end{array}$ & $\begin{array}{c}34 \\
225 \\
68\end{array}$ & $\begin{array}{c}34 \\
2.8 \\
200 \\
76\end{array}$ & $\begin{array}{c}28 \\
2.0 \\
200 \\
68\end{array}$ & $\begin{array}{c}12 \\
2.5 \\
200 \\
83\end{array}$ & $\begin{array}{c}24 \\
1.7 \\
150 \\
54\end{array}$ & $\begin{array}{c}35 \\
2.0 \\
100 \\
20\end{array}$ & $\begin{array}{c}104 \\
2.0 \\
100 \\
23\end{array}$ \\
\hline
\end{tabular}


those who had carditis without polyarthritis or those who had both polyarthritis and carditis. We were unable to find a correlation between the severity of the disease and the degree of titer elevation. This finding does not agree with the experience of Coburn and Pauli who reported distinctly higher titers in patients with intense or prolonged rheumatic activity than in patients whose rheumatism was of brief duration or mild character. Of the 139 patients with inactive rheumatic heart disease, 35 gave a history of a recent upper respiratory infection and 104 did not. The per cent that showed an elevated titer in these two groups was practically the same, about 20 per cent.

\section{B. Chorea}

Although we believe Sydenham's chorea should be considered a manifestation of rheumatic fever, we have analyzed our data in these cases separately in view of recent reports questioning this relationship (10). The sera of 29 patients with chorea have been studied." In most instances there was no evidence of organic heart disease and no history of polyarthritis or previous upper respiratory infections. The ages varied from 5 to 21 years.

Sixty-seven per cent of the patients with or without a preceding upper respiratory infection showed an antistreptolysin titer above 100 units. $^{3}$ The results with patients having chorea are comparable to the incidence of elevated titers in the group of patients with active rheumatic carditis and polyarthritis discussed above.

Twenty patients were treated with fever therapy, the hyperpyrexia being induced either by repeated typhoid vaccine injections or by means of the hypertherm. As has been previously noted by Todd (4) and by Coburn and Pauli (5), typhoid vaccine injections appeared to have no influence on the antistreptolysin titer. Similarly, fever induced by the hypertherm seemed to have no effect on the titer.

We could find no strict correlation between the

4 We are grateful to Dr. Charles H. Smith and to the late Dr. Lucy P. Sutton for permitting us to study 18 cases from the Children's Medical Service of Bellevue Hospital.

3 Longcope (8) reports that of 8 cases of chorea, 7 showed a level above 100 units. age of the patient, the severity of the chorea, and the height of antistreptolysin titer.

\section{ANTISTREPTOLYSIN TITER IN ARTHRITIS}

\section{A. Rheumatoid arthritis}

Blair and Hallman (9) found that of $45 \mathrm{pa}$ tients with rheumatoid arthritis, 15 showed a high antistreptolysin titer. Longcope (8) observed that the antibody level was raised in 25 of 55 cases. Dawson and Olmstead (11) studied 219 cases and concluded that in the great majority of those whose illness was of long duration the titer was within normal limits, whereas in the cases of recent and particularly of acute onset, a significant number showed an abnormal titer.

We determined both the agglutinin titer and antistreptolysin titer of 205 sera from 72 patients with rheumatoid arthritis. The same strain of hemolytic streptococcus was used as an antigen for testing the content of both antibodies. ${ }^{\circ}$ Record was made of any history of a preceding upper respiratory infection and the duration of the disease. As will be seen from Table V, 85 per cent of the patients showed a normal titer and the median was 50 units. Of the 13 patients who had suffered with this condition for less than one year, 9 or 69 per cent gave normal titers; of the remaining 4 with titers above 100 units, 3 reported a recent upper respiratory infection. Of the 11 patients in the entire series with elevated antistreptolysin values, 36 per cent gave a history of recent respiratory infection, whereas only 10 per cent of patients with normal titers presented such a history. Thus, in most of our cases of rheumatoid arthritis, the antistreptolysin titer was within normal limits regardless of the stage of the disease or the severity of clinical symptoms. We found no correlation between the antistreptolysin and the hemolytic streptococcus agglutinin titers; three-quarters of the patients with high agglutinin titers $(1: 80$ to $1: 640)$ had a normal antistreptolysin titer.

\section{$B$. Other types of arthritis}

Antistreptolysin determinations were made in 9 types of arthritis besides rheumatic fever and

${ }^{6}$ We used N. Y. 5 as the antigen for the agglutinin titer and WPRL for the production of streptolysin. We subsequently learned that these two labels refer to the same strain. 
TABLE $V$

Antistreptolysin titer in 72 patients with rheumatoid arthritis and its relation to hemolytic streptococcus agglutinin titer, upper respiratory infections and duration of illness*

\begin{tabular}{|c|c|c|c|c|c|c|c|c|c|}
\hline \multirow{2}{*}{ Titer } & \multirow{2}{*}{$\begin{array}{l}\text { Num- } \\
\text { ber of } \\
\text { par- } \\
\text { tients }\end{array}$} & \multirow{2}{*}{$\begin{array}{r}\text { Num- } \\
\text { ber of } \\
\text { determi- } \\
\text { nations }\end{array}$} & \multirow{2}{*}{$\begin{array}{l}\text { Early } \\
\text { stages; } \\
\text { less } \\
\text { than } \\
\text { one } \\
\text { year }\end{array}$} & \multirow{2}{*}{$\begin{array}{c}\text { Late } \\
\text { stages; } \\
\text { more } \\
\text { than } \\
\text { one } \\
\text { yeart }\end{array}$} & \multirow{2}{*}{$\begin{array}{l}\text { Preced- } \\
\text { ing upper } \\
\text { reopira- } \\
\text { tory in- } \\
\text { fection }\end{array}$} & \multicolumn{4}{|c|}{$\begin{array}{l}\text { Hemolytic streptococe us } \\
\text { agglutinin titer }\end{array}$} \\
\hline & & & & & & $\begin{array}{l}\text { Neg- } \\
\text { ative }\end{array}$ & $\left|\begin{array}{c}1: 20 \\
0 \text { or } \\
1: 40\end{array}\right|$ & $\begin{array}{c}1: 80 \\
\text { or } \\
1: 160\end{array}$ & $\begin{array}{l}1: 320 \\
\text { or } \\
1: 640\end{array}$ \\
\hline $\begin{array}{c}\text { units } \\
\text { per cc. } \\
\text { Lese than } \\
25 \\
25 \\
50 \\
100 \\
150 \\
200 \\
250 \\
350 \\
400\end{array}$ & $\begin{array}{r}5 \\
12 \\
24 \\
20 \\
2 \\
3 \\
4 \\
1 \\
1\end{array}$ & $\begin{array}{r}8 \\
15 \\
67 \\
63 \\
5 \\
4 \\
21 \\
9 \\
13\end{array}$ & $\begin{array}{l}0 \\
4 \\
3 \\
2 \\
1 \\
1 \\
2 \\
0 \\
0\end{array}$ & $\begin{array}{r}5 \\
5 \\
18 \\
17 \\
0 \\
2 \\
2 \\
1 \\
1\end{array}$ & $\begin{array}{l}1 \\
2 \\
1 \\
2 \\
2 \\
1 \\
1 \\
1 \\
0 \\
1\end{array}$ & $\begin{array}{l}1 \\
0 \\
4 \\
7 \\
1 \\
0 \\
0 \\
1 \\
0\end{array}$ & $\begin{array}{l}2 \\
0 \\
0 \\
1 \\
0 \\
0 \\
1 \\
0 \\
0\end{array}$ & $\begin{array}{r}1 \\
6 \\
11 \\
4 \\
0 \\
1 \\
0 \\
0 \\
0\end{array}$ & $\begin{array}{l}1 \\
6 \\
9 \\
8 \\
1 \\
2 \\
3 \\
0 \\
1\end{array}$ \\
\hline
\end{tabular}

* Where more than one determination was done in a given case, only the maximum titer was considered.

f In 9 of the 72 cases the exact duration of the illness was not determined. Of these the titer was 25 units in 3,50 units in 3,100 units in 2 and 150 units in 1.

rheumatoid arthritis. The criteria for classifying these types have been described elsewhere (12). The bases for differentiation were purposely made very strict and all cases about which we had any doubt were listed in one of the two " unclassified" categories. The results are presented in Table VI. We studied 493 serum specimens of 320 patients. Eighty-five per cent of the entire group had titers within normal limits. Of the 15 per cent showing a high antibody level, at least one-fourth were known to have had a recent upper respiratory infection. The highest percentage of elevated titers was found in the patients with unclassified types of arthritis, some of whom probably had atypical rheumatic fever. It should be noted that 2 patients with suppurative arthritis due to hemolytic streptococcus showed abnormal titers.

Table VII summarizes the titers observed in all

TABLE VII

Summary of the antistreptolysin titer (units per cc.) of all cases of arthritis studied

\begin{tabular}{c|c|c|c}
\hline \hline Type of arthritis & $\begin{array}{c}\text { Number of } \\
\text { patients }\end{array}$ & Median titer & $\begin{array}{c}\text { Per cent of } \\
\text { patients with } \\
\text { titers above } \\
100\end{array}$ \\
\hline $\begin{array}{c}\text { Rheumatic poly- } \\
\begin{array}{c}\text { arthritis...... } \\
\text { Rheumattoid } \\
\text { arthritis...... }\end{array}\end{array}$ & 135 & units per cc. & per cent \\
$\begin{array}{c}\text { All other types of } \\
\text { arthritis*..... }\end{array}$ & $318+$ & 50 & 74 \\
\hline
\end{tabular}

* It should be noted that in this group have been included the unclassified types of arthritis, some of which may have been atypical rheumatic or rheumatoid arthritis. These unclassified types have been listed separately in Table VI.

t The 2 cases of hemolytic streptococcus arthritis have not been included.

TABLE VI

Antistreptolysin titer (units per cc.) in various types of arthritis *

\begin{tabular}{|c|c|c|c|c|c|c|c|c|c|c|c|c|c|c|}
\hline \multirow[b]{2}{*}{ Type of arthritis } & \multirow{2}{*}{$\begin{array}{c}\text { Num- } \\
\text { ber of } \\
\text { patients }\end{array}$} & \multirow{2}{*}{$\begin{array}{l}\text { Num- } \\
\text { ber of } \\
\text { deter- } \\
\text { mina- } \\
\text { tions }\end{array}$} & \multirow[b]{2}{*}{$\underset{\text { Median }}{\text { titer }}$} & \multirow{2}{*}{$\begin{array}{c}\text { Per } \\
\text { cent } \\
\text { above } \\
100\end{array}$} & \multicolumn{9}{|c|}{ Number of patients with the following titers: } & \multirow{2}{*}{$\begin{array}{l}\text { Upper } \\
\text { respir- } \\
\text { atory } \\
\text { infec- } \\
\text { tion }\end{array}$} \\
\hline & & & & & $\begin{array}{l}\text { Less } \\
\text { than } \\
25\end{array}$ & 25 & 50 & 100 & 150 & 200 & 250 & 300 & $\begin{array}{l}\text { Above } \\
300\end{array}$ & \\
\hline & & & $\begin{array}{c}\text { units } \\
\text { per ce. }\end{array}$ & $\begin{array}{l}\text { per } \\
\text { cent }\end{array}$ & & & & & & & & & & \\
\hline Osteo-arthritis . . . . . . & 106 & 148 & 50 & 3 & 6 & 33 & 45 & 19 & 2 & 0 & 1 & 0 & 0 & 1 \\
\hline Gonococcal. . . . . . . & 60 & 100 & 50 & 10 & 2 & 11 & 24 & 17 & 3 & 1 & $\mathbf{0}$ & 1 & 1 & 3 \\
\hline $\begin{array}{l}\text { Tuberculous........ } \\
\text { Hemolytic strepto- }\end{array}$ & 5 & 5 & 50 & 20 & 0 & 1 & 3 & 0 & 1 & $\mathbf{0}$ & $\mathbf{0}$ & 0 & 0 & 0 \\
\hline $\begin{array}{l}\text { coccal (suppura- } \\
\text { tive) } \ldots \ldots \ldots \ldots\end{array}$ & 2 & 2 & & 100 & $\mathbf{0}$ & 0 & 0 & 0 & 0 & 1 & 0 & $\mathbf{0}$ & 1 & $\mathbf{0}$ \\
\hline $\begin{array}{l}\text { Meningococcal ...... } \\
\text { Spondylitis }\end{array}$ & 2 & 2 & & 0 & 0 & 0 & 1 & 1 & 0 & 0 & 0 & 0 & 0 & 0 \\
\hline Ankylopoetica .... & 6 & 12 & 100 & 16 & 1 & $\mathbf{0}$ & 1 & 3 & 1 & 0 & $\mathbf{0}$ & $\mathbf{0}$ & 0 & $\mathbf{0}$ \\
\hline Gout . . . . . . . . . . & 10 & 20 & 50 & 0 & 0 & 3 & 4 & 3 & 0 & 0 & 0 & 0 & 0 & $\mathbf{0}$ \\
\hline $\begin{array}{l}\text { Infectious-type. } \\
\text { unclassified } \ldots \ldots \ldots\end{array}$ & 95 & 152 & 50 & 29 & 5 & 14 & 28 & 20 & 12 & 6 & 3 & 7 & 0 & 7 \\
\hline Wholly unclassified. . & 34 & 52 & 50 & 23 & 2 & 7 & 9 & 8 & 4 & 3 & 1 & 0 & 0 & 2 \\
\hline Total.... & 320 & 493 & 50 & 15 & 16 & 69 & 115 & 71 & 23 & 11 & 5 & 8 & 2 & 13 \\
\hline
\end{tabular}

* When more than one determination was done only the maximum titer was considered. The figures under the respective titers represent number of patients having such titers. The last vertical column indicates the number of patients with titers above 100 known to have had recent upper respiratory infections. 
cases of arthritis studied by us. It is interesting that the incidence of elevated titers in the patients with miscellaneous arthritides is exactly the same as in the group with rheumatoid arthritis. In this series of patients, then, rheumatoid arthritis was no more apt to be accompanied by elevated antistreptolysin titers than were such diseases as gonococcal and tuberculous arthritis. The figures in this table also show that the titer may be used as a diagnostic aid in cases of acute arthritis; when elevated, it is suggestive (although not diagnostic) of rheumatic polyarthritis.

\section{ANTISTREPTOLYSIN TITER IN OTHER CONDITIONS}

Erythema nodosum may be encountered in cases of infection with hemolytic streptococcus and in tuberculosis. We have made observations on 6 patients with this skin manifestation. Only 1 patient had tuberculosis, and she had a titer of 50 units. In the remaining 5 , the maximum titers were $500,350,250,150$, and 50 . Conclusions cannot be drawn from such a small series. If additional studies should corroborate these results, antistreptolysin determinations might be a useful aid in separating the cases of erythema nodosum associated with hemolytic streptococcus infection from other types.

Acute pericarditis, with or without effusion, is associated, in most instances, with rheumatic fever or tuberculosis. Clinically, the differential diagnosis in some cases may be very difficult. We have observed 7 cases of acute pericarditis. In 6 , this condition developed in the course of rheumatic fever, and every patient showed a titer above $100(400,300,200,150,150)$. The titer in the 1 case of tuberculous origin was 50 units.

Lupus erythematosus disseminatus and periarteritis nodosum. Because of the similarities between some features of these two diseases and rheumatic fever, it was considered of interest to make antistreptolysin determinations in them. Two patients with each disease (confirmed at necropsy in each instance) were followed with serial bleedings over many months up to the time of death. The antistreptolysin titers were well within normal limits at all times.

\section{DISCUSSION}

A new serologic test such as the antistreptolysin titration is of interest to the clinician chiefly from two points of view: (1) the information it may give as to the etiology of certain diseases, and (2) its possible usefulness as a prognostic and diagnostic aid.

All investigators here cited, with the exception of Wilson and her associates, have found an elevated antistreptolysin titer in more than 80 per cent of patients with rheumatic fever. Both Coburn and Todd concluded from this that patients with rheumatic fever are responding immunologically to a hemolytic streptococcus infection. Wilson, Wheeler and Leask (6), on the other hand, believed that in their rheumatic patients "the rise of the level of antistreptolysin in the serum following respiratory infections seemed directly related to the extent of the local and constitutional symptoms irrespective of the presence of hemolytic streptococcus in the pharyngeal flora." They reported also that only one-third of their patients with active rheumatic fever who did not have respiratory infections exhibited a rise in antistreptolysin titer and that the titer of active rheumatic subjects experiencing respiratory infections was similar to that of inactive rheumatic subjects with these infections.

Our results do not bear out these findings of Wilson and her associates, although the antistreptolysin titers did tend to be higher in patients who developed rheumatic fever after distinct respiratory infections than in those whose rheumatic attacks were not preceded by such infections. Whether our patients who gave no history of respiratory infections actually had none, we cannot be certain, since we saw them, in most instances, only after the onset of rheumatic symptoms, but it can be said that these patients did not have respiratory infections of sufficient severity to be remembered by them. Our findings are largely in accord with those of Coburn and Pauli (5) although not in agreement with their report (13) that the onset of rheumatic fever coincided with a sharp rise in antistreptolysin titer. Indeed, many of our patients showed no rise until weeks after the onset of rheumatic fever and in a fair number the titer did not rise at all during periods of observation as long as 6 months. In this connection, however, it must be emphasized that some patients with such known hemolytic streptococcal diseases as scarlet fever and erysipelas show no antistreptolysin increase; so that the negative find- 
ings in some rheumatic patients are of little weight in arguing against the hemolytic streptococcal theory of etiology of that disease.

Since it has repeatedly been shown that a rise in the antistreptolysin level occurs only after infection with hemolytic streptococci and not after infection with other micro-organisms, our results, we believe, are in support of the view that there is an important relationship between rheumatic fever and hemolytic streptococcal infection. Whether the latter acts in a primary or merely in a contributory capacity, however, cannot be stated with such confidence.

In view of the lack of parallelism between the height of antistreptolysin titer and the severity of rheumatic fever, as mentioned previously, the test would appear to have little value in prognosis. As an aid in the differential diagnosis of rheumatic fever, the antistreptolysin test obviously must be interpreted with caution since it is in no way specific for that disease but merely indicates a present or recent infection with hemolytic streptococci. Nevertheless, the antistreptolysin titer is so constantly increased in rheumatic fever and so generally normal in other diseases involving the joints, that we have found the procedure distinctly useful as a confirmatory test, particularly in clinically atypical cases. Whether or not measurement of the antistreptolysin titer may be helpful in deciding whether the infectious process is active or inactive in rheumatic patients is not certain. Here again the test gives no specific indication of rheumatic activity but it does afford one more bit of presumptive evidence to be interpreted in the light of the clinical and other laboratory findings.

\section{SUMMARY}

1. The results of 1,539 determinations of the antistreptolysin titers of the sera of 817 patients are here reported.

2. In normal individuals we have found the median titer to be 25 units and the normal maximum titer to be 100 units per cc.

3. Eighty per cent of patients with scarlet fever showed a rise in antistreptolysin titer during the course of the disease, but in only 48 per cent did it rise above 100 units in the 3- to 4-week period of observation.

4. The majority of all patients with active rheumatic fever showed a high antistreptolysin titer.
The incidence of elevated titers bore no relation to the various clinical manifestations of the rheumatic infection. Those patients whose illness was preceded by an upper respiratory infection sufficiently severe to be remembered, showed this immunological response more commonly than those without a history of preceding upper respiratory infection. Patients with inactive rheumatic heart disease usually had normal titers.

5. The majority of patients with chorea showed an increased titer regardless of whether or not the condition was associated with heart disease or polyarthritis. Age, severity of illness, and fever therapy did not seem to influence the antibody titer.

6. Patients with rheumatoid arthritis, as a rule, did not show an abnormal antistreptolysin titer. This is in sharp contrast to the high incidence of raised hemolytic streptococcus agglutinin titers observed in these patients even when the identical strain was used as an antigen to measure both antibodies.

7. Patients with other types of arthritis similarly failed to show an elevated antistreptolysin titer in a significant percentage of cases.

8. Because three-quarters of the patients with rheumatic polyarthritis showed an abnormally high titer and those with other forms of joint diseases did not, the test was found helpful in diagnosis.

9. Patients with erythema nodosum of hemolytic streptococcal origin and patients with acute pericarditis of rheumatic type had, as a rule, an abnormal titer. When, however, these conditions were of a tuberculous origin, the titer was within normal limits. Here again the serological determination may be of diagnostic value. Further studies are needed to corroborate this impression since the number of cases here reported is small.

10. Several patients with lupus erythematosus disseminatus and periarteritis nodosa had a normal antistreptolysin titer.

11. In no disease have we found a correlation between the antistreptolysin titer and the severity of the illness; hence the titer is of doubtful prognostic significance.

12. Finally, it must be borne in mind that an elevated antistreptolysin titer may be found in a patient suffering with a disease not related to, but merely preceded by a hemolytic streptococcus in- 
fection. To reason that the elevated titer indicates that the presenting disease is of hemolytic streptococcal origin may lead to an erroneous diagnosis.

We wish to express our thanks to Mrs. Rose C. Alexander for her help in carrying out the various technical procedures.

\section{BIBLIOGRAPHY}

1. McEwen, C., Bunim, J. J., and Alexander, R. C., Bacteriologic and immunologic studies in arthritis. II. Results of various immunologic tests in different forms of arthritis. J. Lab. and Clin. Med., 1936, 21, 465.

2. Hodge, B. E., and Swift, H. F., Varying hemolytic and constant combining capacity of streptolysins; influence on testing for antistreptolysins. J. Exper. Med., 1933, 58, 277.

3. von Hellens, O., Untersuchung uber Streptolysin. Centralbl. f. Bakterial., 1 Abt. Orig., 1913, 68, 602.

4. Todd, E. W., Antihemolysin titres in haemolytic streptococcal infections and their significance in rheumatic fever. Brit. J. Exper. Path., 1932, 13, 248.

5. Coburn, A. F., and Pauli, R. H., Studies on the relationship of streptococcus hemolyticus to the rheumatic process. III. Observations on the immunological responses of rheumatic subjects to hemolytic streptococcus. J. Exper. Med., 1932, $56,651$.

6. Wilson, M. G., Wheeler, G. W., and Leask, M. M., The relation of upper respiratory infections to rheumatic fever in children. II. Antihemolysin titres in respiratory infections and their significance in rheumatic fever in children. J. Clin. Invest., 1935, 14, 333.

7. Griffiths, G. J., Antihaemolysin titres in chronic rheumatic and allied diseases. Lancet, 1934, 2, 251.

8. Longcope, W. T., Studies of variations in antistreptolysin titer of blood serum from patients with hemorrhagic nephritis; observations on patients suffering from streptococcal infections, rheumatic fever, and acute and chronic hemorrhagic nephritis. J. Clin. Invest., 1936, 15, 277.
9. Blair, J. E., and Hallman, F. A., Streptococcal agglutinins and antistreptolysins in rheumatoid (atrophic) arthritis. J. Clin. Invest., 1935, 14, 505.

10. (a) Coburn, A. F., and Moore, L. V., The independence of chorea and rheumatic activity. Am. J. Med. Sc., 1937, $193,1$.

(b) Gerstley, J. R., Wile, S. A., Falstein, E. I., and Gayle, M., Chorea : is it a manifestation of rheumatic fever? J. Pediat., 1935, 6, 42.

11. Dawson, M. H., and Olmstead, M., Antistreptolysin titers in rheumatoid arthritis. Proc. Soc. Exper. Biol. and Med., 1936, 34, 82.

12. McEwen, C., Alexander, R. C., and Bunim, J. J., Bacteriologic and immunologic studies in arthritis. I. Results of blood cultures in different forms of arthritis. J. Lab. and Clin. Med., 1936, 21, 453.

13. Coburn, A. F., and Pauli, R. H., Studies on the immune response of the rheumatic subject and its relationship to activity of the rheumatic process. VI. The significance of the rise of antistreptolysin level in the development of rheumatic activity. J. Clin. Invest., 1935, 14, 769.

14. Coburn, A. F., and Pauli, R. H., Studies on the immune response of the rheumatic subject and its relationship to activity of the rheumatic process. I. The determination of antistreptolysin titer. J. Exper. Med., 1935, 62, 129.

15. Myers, W. K., and Keefer, C. S., Antistreptolysin content of the blood serum in rheumatic fever and rheumatoid arthritis. J. Clin. Invest., 1934, 13, 155.

16. Longcope, W. T., Studies of variations in antistreptolysin titer of blood serum from patients with hemorrhagic nephritis; control observations on healthy individuals and patients suffering from diseases other than streptococcal infections. J. Clin. Invest., 1936, 15, 269.

17. Morales-Otero, P., and Pomales-Lebrón, A., Antistreptolysin content of sera from cases of recurrent tropical lymphangitis. Proc. Soc. Exper. Biol. and Med., 1934, 31, 1170.

18. Zuger, B., Group infection and immunity during a scarlet fever epidemic in a boys' school. Am. J. Hyg., 1935, 21, 588. 